\title{
Production Planning and Control: Improvement Proposal for the Stock Management of a Hotel Located in a Brazilian Metropolitan Region
}

\author{
Cleginaldo Pereira de Carvalho ${ }^{1 *}$, Andreia Cristina Ribeiro Silva ${ }^{2}$
}

\author{
${ }^{1}$ Department of Industrial Engineering, University of the State of São Paulo, Faculty of Engineering of Guaratinguetá, São Paulo, Brazil. \\ Avenida Dr. Ariberto Pereira da Cunha, 333, Pedregulho, Zip Code: 12516-410 \\ *Corresponding author \\ ${ }^{2}$ National Institute for Space Researches, INPE, Regional Unit of Cachoeira Paulista, São Paulo, Brazil, Rodovia Presidente Vargas, km \\ 40, Zip Code: $12630-970$
}

Received: 25 Nov 2020; Received in revised form: 12 Dec 2020; Accepted: 18 Dec 2020; Available online: 22 Dec 2020 (C)2020 The Author(s). Published by Infogain Publication. This is an open access article under the CC BY license (https://creativecommons.org/licenses/by/4.0/).

\begin{abstract}
Studies show that the application of Production Planning and Control (PCP) in micro and small companies, mainly in the service sector, encounters many resistance from companies. This work explored this finding by conducting a study in a hotel located in the Metropolitan Region of the Paraíba Valley and North Coast located in the Sao Paulo State, Brazil, with the aim of detailing the situation from the perspective of Production Engineering. The methodology of the bibliographic research in periodicals on the application of the PCP in micro and small companies, in the area of services and in the hotel sector was used, and the results confirmed the possibility of improvements for the sector, contributing to a more rational management of resources and an increase in the reliability of the services provided by the enterprise.
\end{abstract}

\section{Keywords-Hotel Sector, Inventory Control, Production Planning and Control.}

\section{INTRODUCTION}

At the beginning of 2019 , the [1] projected a $3 \%$ to $5 \%$ growth in the hotel occupancy rate for the current year. Data from the [2] point out that in 2016, the Metropolitan Region of Vale do Paraíba and North Coast (RM Vale) generated $4.8 \%$ of Gross Domestic Product (GDP), with approximately 2.5 million inhabitants in 2018. Combining these data with the strong religious tourism that the Paraíba Valley provides, headed by the Basilica of Our Lady Conception Aparecida, the Sanctuary Frei Galvão and Canção Nova, one can point to the hotel sector of the region a horizon of opportunities. In this context, this study was conducted at a hotel located in RM Vale, here called Hotel Zeta.

From this synthesis of the hotel sector at RM Vale, one can conceptualize the PCP. For the author [3], Planning and Control is the "conciliation of the operation potential of supplying products and services with the demand of its consumers". It is a set of activities that are performed daily in order to ensure that the manufacturing operations of the organization occur in a continuous way [3]. [4] also state that "PCP is also an information transformation system, because it receives information about the existing stocks, expected sales, product line, production capacity".

The PCP acts as an internal integrator of the organization: planning and control, finance, marketing, sales, purchasing, product engineering and production [5]. It is related to planning and control when preparing demand forecasts and analyzing production capacity when determining the organization's annual planning; with finances the PCP has a direct relationship with the budget forecasts that will be necessary to achieve the goals proposed by the planning; it is also directly involved in defining the human resources that will be needed to fulfill the planned production; With marketing and sales, the PCP maintains a close relationship in order to ensure that the goals are feasible from the point of view of all productive resources; with product engineering and production, the relationship becomes even closer, because it is necessary to ensure not only the capability of the processes, but also 
to schedule the production, developing its control and feedback with continuous improvements.

At first, this work sought to study the possibility of implementing the PCP in a micro or small company, checking the gains that could be achieved. However, a small search in the Periodical Portal of the Coordination for the Improvement of Higher Level Personnel (CAPES) and in the site of the Brazilian Association of Production Engineering (ABEPRO) showed that the application of PCP in micro and small companies is still a factor that meets many resistance from companies, especially when it comes to the service production sector.

The evidence on PCP studies in the hotel sector confirms this characteristic found in relation to micro and small companies, however, it also demonstrates that the sector shares the same processes of an organization producing tangible goods, which makes a hotel susceptible to the same tools and methodologies of PCP [6]. This finding aroused the interest of understanding a little beyond the possible gains with the application of the PCP, it even suggested a niche that could be explored for future egresses, and contributed to the objective of the study in detailing the reality of Hotel Zeta from the perspective of Production Engineering, delimited by the application of PCP methodologies and tools and present a solution proposal for one of the problems that was diagnosed in the company.

The work was carried out based on bibliographic research in journals on the application of the PCP in micro and small enterprises, in the area of services and in the hotel sector, with due emphasis on planning and stock control in the context addressed. From these bibliographic researches, some data from Hotel Zeta were collected, some PCP tools were applied, and the results were analyzed and compared to the reality of the enterprise. he final product of the whole study, besides the proposal of initial use of an inventory control spreadsheet that proved to be easy to understand and implement should the company choose to use the resource, revealed that the methodology and tools can result in promising improvements for the hotel sector and, specifically in the case of inventory planning and control, it contributes to a more rational management of resources, protecting from critical shortages and increasing the reliability of supplies in the services provided [7].

\section{BIBLIOGRAPHICAL REVIEW}

The expected professional profile of a Production Engineer, among other requirements, is the ability to act in the planning and improvement of productive systems of goods and services and to develop solutions to complex problems within these systems [8]. In production management, stock planning and control is a topic directly linked to Production Planning and Control (PCP) activities, hence the importance of the topic for the formation of the production engineering student.

As an area of wide application in production engineering, to study the application of PCP at Hotel Zeta, we started the bibliographic review in books, journals and other publications, such as newsletters and articles on sites available on the Internet, involving topics on the following applications of PCP: in micro and small businesses, in the services area, in the hotel sector and in stock management. In order to carry out the research in journals, the CAPES Journals Portal and ABEPRO's website were consulted, using the words: production planning and control, hotel sector, micro and small companies, services and stock management as descriptors. The main results for the purposes of the study were gathered in the following table 1:

Table 1: Summary of the bibliographic review in journals: results and gaps found

\begin{tabular}{|l|l|l|l|l|}
\hline $\begin{array}{l}\text { PCP } \\
\text { Applications }\end{array}$ & Objectives & Results & $\begin{array}{l}\text { Suggestions / Gaps } \\
\text { Publications } \\
\text { Researched }\end{array}$ \\
\hline $\begin{array}{l}\text { Micro and } \\
\text { small }\end{array}$ & $\begin{array}{l}\text { Application of PCP } \\
\text { enterprises } \\
\text { resources to improve } \\
\text { the performance of a } \\
\text { micro company; use } \\
\text { of PCP resources } \\
\text { such as Demand } \\
\text { Forecasting, short, } \\
\text { medium and long } \\
\text { term planning; } \\
\text { improvement of the }\end{array}$ & $\begin{array}{l}\text { Development of a decision support } \\
\text { methodology proposed to assist in the } \\
\text { development of the PCP for small } \\
\text { businesses; increase in delivery } \\
\text { punctuality; reduction of lead time; } \\
\text { reduction of waiting time in line; } \\
\text { increase in capacity utilization; } \\
\text { identification of variables and basic } \\
\text { indicators for the implementation of the }\end{array}$ & $\begin{array}{l}\text { Application of other } \\
\text { improvement tools } \\
\text { (stock control, } \\
\text { feasibility study, } \\
\text { action plan); adoption } \\
\text { of software for the } \\
\text { optimization of } \\
\text { programming; how to } \\
\text { minimize the risk, } \\
\text { what is the impact of }\end{array}$ & \begin{tabular}{l}
5 \\
\hline
\end{tabular} \\
\hline
\end{tabular}




\begin{tabular}{|c|c|c|c|c|}
\hline & $\begin{array}{l}\text { PCP of a small } \\
\text { company; process } \\
\text { mapping. }\end{array}$ & PCP. & $\begin{array}{l}\text { restructuring in the } \\
\text { decision-making } \\
\text { process; critical } \\
\text { analysis of processes. }\end{array}$ & \\
\hline Services area & $\begin{array}{l}\text { Use of PCP to } \\
\text { improve planning of } \\
\text { hosting services; } \\
\text { sales and operations } \\
\text { planning in the } \\
\text { service sector. }\end{array}$ & $\begin{array}{l}\text { Improvement of the management of } \\
\text { services in the capacity of attendance } \\
\text { with quality and efficiency; capture, } \\
\text { organization and analysis of data } \\
\text { referring to the demand and the capacity } \\
\text { of the company. }\end{array}$ & $\begin{array}{l}\text { Application of other } \\
\text { improvement tools. }\end{array}$ & 2 \\
\hline Hotel Sector & $\begin{array}{l}\text { Evaluate restaurants } \\
\text { located in hotels with } \\
\text { a focus on } \\
\text { management } \\
\text { improvement; } \\
\text { evaluation of the } \\
\text { hotel supply chain } \\
\text { and its impact on } \\
\text { operational and } \\
\text { financial } \\
\text { performance. }\end{array}$ & $\begin{array}{l}\text { Application of the quality tools; } \\
\text { application of the PCP methodology in } \\
\text { the evaluation of the supply chain. }\end{array}$ & $\begin{array}{l}\text { Application of other } \\
\text { PCP tools; study of } \\
\text { demand management } \\
\text { in the supply chain } \\
\text { and inclusion of other } \\
\text { means of hosting. }\end{array}$ & 3 \\
\hline $\begin{array}{l}\text { Inventory } \\
\text { Management }\end{array}$ & $\begin{array}{l}\text { Importance of stock } \\
\text { control processes } \\
\text { and their impacts on } \\
\text { the company's } \\
\text { growth impact; } \\
\text { demand forecasting } \\
\text { and stock } \\
\text { management; ABC } \\
\text { curve application; } \\
\text { JIT and Kankan } \\
\text { application to } \\
\text { optimize the stock; } \\
\text { application of the } \\
\text { lean company tools } \\
\text { in a civil } \\
\text { construction } \\
\text { company. }\end{array}$ & $\begin{array}{l}\text { Application of stock control techniques } \\
\text { and company readaptation showing } \\
\text { favorable results; tools and methods of } \\
\text { demand forecasting and stock } \\
\text { management allow a more efficient, } \\
\text { faster and intuitive control; ABC curve } \\
\text { allows identifying the items of greatest } \\
\text { financial importance; JIT and Kanban } \\
\text { are not restricted to the industrial } \\
\text { scenario, and can contribute to reducing } \\
\text { inventory and costs even in } \\
\text { environments where robust IT systems } \\
\text { are lacking; use of MRP in the } \\
\text { development of a tool, using Visual } \\
\text { Basic (VBA) programming language in } \\
\text { MS Excel; use of physical inventory of } \\
\text { inventory; use of Lean practices and } \\
\text { visual management for the construction } \\
\text { industry; supply the demand and absence } \\
\text { of a safety stock. }\end{array}$ & $\begin{array}{l}\text { Implementation of } \\
\text { continuous stock } \\
\text { control; safety stock } \\
\text { by product type; } \\
\text { application of other } \\
\text { PCP methodologies; } \\
\text { implementation of } \\
\text { MRP II; detailed } \\
\text { analysis of stock } \\
\text { control in restaurants } \\
\text { from PCP tools. }\end{array}$ & 15 \\
\hline
\end{tabular}

From the delimitation of the object of the study and after analysis of the problem in the light of some publications found (table 1), it can be stated that the problem of application of the methodologies and tools of the PCP becomes more scarce when delimiting the space of micro and small companies added to those of service provision. This statement is also mentioned by other authors when they look at the application of the PCP in small and medium enterprises, such as the conclusions presented by the author [9]. In light of this finding, this study involving Hotel Zeta sought to answer some of the questions regarding the following gaps found: application of other improvement tools (stock control), implementation of continuous stock control, and safety stock by type of product. 
Brazil has 6.4 million establishments and of this total, 99\% are micro and small enterprises (MPE) that account for $52 \%$ of jobs with signed portfolio in the private sector [10], which leads to the conclusion of the existence of an expressive niche for the application of PCP methodologies and tools. Studies have shown that this part of the undertakings, together with the services production sector, could become even more productive with methods and techniques of production planning and control.

\subsection{The production of services in the Hotel Sector}

The provision of services in the hospitality sector is directly related to the hospitality industry, although it is not the focus of this research, it is therefore important to emphasize that the activities performed in the provision of services in a hotel are transversal to the universe of this industry. For the author [11], the guest does not have any obligation to return, because he is just making a monetary exchange, being the entrepreneur to satisfy him in the measure and in the expected quality so that he starts to wish a return visit. In front of this statement, to apply the quality tools in the planning and control of the stocks is necessary to guarantee not only the satisfaction of the requirements of the client, but also its fidelity and, of this transaction, the profit for the enterprise. The vision of applying PCP tools in the service sector, especially in the hotel sector, is corroborated by [12] when he states about "the need for evolution in managerial processes in order to obtain primacy in the provision of their services, and therefore ensure survival in a scenario of increasing change.

\subsection{Demand Planning and Inventory Control}

The production process begins with the observation of a client's need, from which a solution is idealized, followed by a demand forecast. The author [5] conceptualizes the demand as the willingness of customers to consume goods and services. From this concept, it can be stated that demand is constantly suffering influences from the economic, operational, political environment: inflation, exchange rate, employment level, fiscal policy, product availability, price, place of sale, politics and trade barriers. In addition to the influences that demand suffers, some patterns in the way demand occurs can also be identified. For example, buying a daily rate at a hotel is a very "oneoff" activity for any citizen, however, for an executive who is always in contact with potential customers and suppliers in charge of a large company, this activity can follow a "repetitive" pattern.

Thus, knowing the demand and understanding its patterns, identifying its trends, is fundamental to perform the demand forecasting [5], being an important factor for the success or failure of a company. As the forecast is an inference about the future, based on real company information, mathematical and statistical methods are used to perform it. It should be noted that there is no forecast that does not carry a margin of error, since it is something inherent to "forecasting". The most used methods for demand forecasting are: moving average (simple or weighted), exponential damping (simple or with trend adjustment), linear regression and multiple regression [7].

Demand forecasting, as a methodology for planning, also has levels of detail of information and decision making, and can be exemplified in Fig. 1 below [5]:

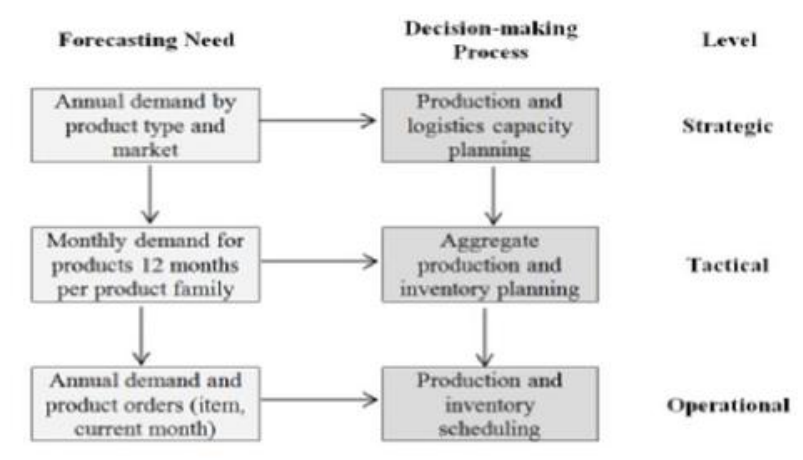

Fig. 1: Demand forecast in production planning

Source: [5]

Demand forecasting techniques are used in conjunction with planning and control, in view of their importance for decision making: how much to ask, when to ask and how to control the system.

Some methodologies suggested by [7] were applied at the Zeta Hotel to support stock decisions: use of the economic lot of purchase (LEC) to support how much to order and application of the ABC curve to support stock management control. It should be noted that, after initial data collection from the enterprise, it was found that the demand forecast per occupation is performed by a company contracted for this purpose. The forecast of the demand for occupied rooms is carried out routinely, as it is from this that the other activities of the enterprise are programmed. This way, the forecast of occupied rooms directly influences the amount of items in stock that will be demanded both for guest service (clothing, hygiene products, etc.) and for those that will be demanded by the food service at Zeta Hotel (breakfast, restaurant, beverage machine, etc.). It should be noted that the authors [13], after conducting a study involving stock of a micro food company, found that the use of the ABC curve contributes to diagnose which stock items need better financial 
management, helping in the formulation and use of a stock policy for each class of item.

According to [7], stock can be defined as the accumulation of material resources needed due to the difference in pace between supply and demand, and this difference directly influences its level of reduction. There are several types of stock, however, considering the Zeta Hotel the work is tied to the safety stock, which is the one necessary to compensate for the uncertainties inherent to demand supply [7]. An excellent stock management can be exemplified by one that does not "stall" the company's financial resources and, also, does not cause losses in customer service [14]. In practice, stock control should take into consideration the characteristics of each business, that is, not always what goes very well in the manufacturing area, will go so well in the service area. The way an inventory is controlled can affect the quality, availability, reliability, flexibility of choice and cost of a supply [7].

\subsection{Planning and Quality Control}

Quality is one of the additional factors directly related to production and can be understood as meeting customer expectations [14]. The authors [15] emphasize quality in the hotel services sector as a factor directly related to customer service, overcoming and satisfaction.

According to Ishikawa, "ninety-five percent of qualityrelated problems can be solved by using seven basic quantitative tools" [16]. These tools are represented by: process diagrams, Pareto analysis, cause and effect diagrams, correlation diagrams, histograms, process control charts and check sheets. To support the solution of the Zeta Hotel stock problem, the quality tools will be used: Pareto analysis and cause and effect diagrams.

Pareto's analysis allows to analyze in a fast and direct way, among several listed problems, which produce the greatest effects, consequently allowing to create actions to solve them first. After the second interview with a representative of the Zeta Hotel, several shortcomings related to stock management were raised. The Pareto analysis tool was applied and figure 3 was generated to visualize the problem.

The cause and effect diagram, also called the Ishikawa or herringbone diagram, is a simple tool, but has proven very effective in problem analysis. [14] suggest its use in combination with Pareto analysis, further stating that, in the case of manufacturing, the 6Ms (machine, labor, measurement medium, material, method and environment) are usually used. In the case of service operations, the 4Ps (places, procedures, people and politics) are used.
Stock planning and control is the target of many researches, from the PCP point of view, because its tools tend to cause great positive impact of the management of this activity inside any researched company. This statement can be confirmed by means of the surveys in periodicals mentioned in table 1. The author [17] strengthens this idea when he points out as one of the possible technical restrictions for the implementation of PCP in small companies the absence of a quality control system.

\section{METHODOLOGY}

This study has an applied nature, exploratory objective and qualitative approach. As for the method employed, it is an action research, since the student will be participating in a cycle in which research is done on the object of study and proposes a change to improve his practice [18]. The action-research method is characterized by a cycle that can be represented by four phases: planning of an improvement of the practice; action to implement what was planned; monitoring of the action and description of its effects; and evaluation of the results of the action taken. This cycle requires a constant action and at the same time an investigation [18].

The use of this method is justified, since the study in question begins with an investigative look in the search for the problem, at the same time as the applications of the PCP are investigated more rigorously. From these two steps, a solution is outlined, the planning is done and the behavior of the application of this solution is observed, measuring - even if statistically - its effects and results on the investigated problem.

In order to develop the work and find a PCP tool that best fits the scope of the study for implementation in a real company, as well as develop the theoretical basis of the project, the first step to talk about the subject and achieve the objective of the work was the bibliographic research in books and articles involving topics related to: Production Planning and Control, the PCP in small companies, the PCP in Stock Control and the PCP in the Hotel Sector. The initial milestone was the authors [14], as well as articles, monographs and dissertations published in digital repositories ABREPO and CAPES.

The collection of data referring to the Hotel Zeta, object of the investigations of this study, was carried out through the elaboration of research questionnaires and participation in meetings in the researched environment. The face-to-face meetings, in which some initial data were collected and also the characteristics and organization of the stock were observed, were held at the establishment and included the 
participation of one of the hotel owners and one of the students. OpenProject software was used to plan the study schedule, which proved to be a very accessible tool to manage the research project. Some interviews took place through electronic questionnaires for data collection using Google Forms, an online platform. To support the organization and analysis of data in charts and figures, Microsoft Excel® software was used, as well as XMind software.

The seven quality tools listed by the authors [14] were used, and the tools of the Pareto diagram and Ishikawa analysis were discussed at Hotel Zeta. The next step in the investigation of improvements in stock control at Hotel Zeta, from the PCP perspective, was the application of the following tools: ABC curve, economic purchase lot (LEC) and safety stock (ES).

As a final product of the work, a proposal for an improvement solution was presented for Hotel Zeta, however, the decision to implement it was not included in the scope of the study. Thus, the measurement of the results followed the application of inferential statistics, being up to the owners of the enterprise to apply or not the suggested tools, in whole or in part.

\section{RESULTS OBTANEID}

The application of PCP in micro and small companies is still a factor that encounters a lot of resistance from companies, especially when it comes to the service production sector. The most common thing in available literature is the finding that the PCP involves activities developed by a Production Support Area, responsible for the coordination and application of productive resources in order to best meet the plans established at the strategic, tactical and operational levels of a plant [3].

The author [9] states that there is a great lack of articles relating PCP to small and medium enterprises and mentions in his analysis that many PCP articles deal with software. This same observation is made by the author [17], that the difficulty of applying PCP in this sector occurs because most of the studies in PCP involve modeling methods that require data entry, which are often not available in small and medium enterprises.

Although the scarcity of work involving the application of the PCP in small and medium enterprises, an analysis in the bibliography consulted showed that the methodology and tools can result in promising improvements for the sector and, specifically in the case of stock planning and control, contributes to a more rational management of resources, protecting from critical shortages and increasing the reliability of supplies in the services provided [7].

Hotel Zeta was chosen to perform an action-research defined by the cycle formed by the revision of theoretical concepts and research in the practice of the methods already employed or the forecasting of improvements that the PCP methodologies can provide. From the first meeting held with one of the owners of Hotel Zeta, it was concluded that stock management was one of the main niches for the application of the study on the implementation of the PCP methodology and tools in the company's service production area. A second analysis, carried out through an interview, highlighted the real problems that the hotel has been facing in stock control planning. Based on this diagnosis, the research was started so that, based on the theoretical reference, it could elaborate a suggestion for the improvement of the activities performed in the hotel and that would prove to be a great opportunity for increasing productivity, with reflexes in the satisfaction of the clients and, consequently, with the possibility of maximizing profit.

The result of the next step, resulting from the research conducted to identify the failures in stock management, can be represented by the following Table 2 and respective Fig. 2:

Table 2: Identifying Zeta Hotel's stock control and planning failures for a period of 90 days (one quarter)

\begin{tabular}{|c|l|c|r|r|}
\hline $\begin{array}{c}\text { Representation } \\
\text { Problem }\end{array}$ & \multicolumn{1}{|c|}{ Problem Reported } & Occurrence & $\begin{array}{c}\text { Individual } \\
\text { Participation } \\
(\%)\end{array}$ & $\begin{array}{c}\text { Accumulated } \\
\text { Participation } \\
(\%)\end{array}$ \\
\hline A & $\begin{array}{l}\text { The stock did not present total control of } \\
\text { its products }\end{array}$ & 90 & 39,82 \\
\hline B & There was expired product in stock & 0 & 0 & 39,82 \\
\hline
\end{tabular}




\begin{tabular}{|c|c|c|c|c|}
\hline $\mathrm{C}$ & $\begin{array}{l}\text { There was a need of some product and, } \\
\text { after verification, it was missing }\end{array}$ & 20 & 8,85 & 48,67 \\
\hline $\mathrm{D}$ & The periodic audit was not performed & 1 & 0,45 & 49,12 \\
\hline $\mathrm{E}$ & $\begin{array}{l}\text { Although it does not exist, the need was } \\
\text { felt for a method to predict what, when } \\
\text { and how much to buy }\end{array}$ & 20 & 8,85 & 57,97 \\
\hline $\mathrm{F}$ & $\begin{array}{l}\text { It was necessary to estimate the cost of } \\
\text { the stock }\end{array}$ & 0 & 0 & 57,97 \\
\hline G & $\begin{array}{l}\text { It was necessary to make separate } \\
\text { controls for the hotel and restaurant stock }\end{array}$ & 30 & 13,28 & 71,25 \\
\hline $\mathrm{H}$ & $\begin{array}{l}\text { It was necessary to know who took } \\
\text { products out of stock, but it was laborious } \\
\text { or impossible to get the information }\end{array}$ & 10 & 4,42 & 75,67 \\
\hline I & $\begin{array}{l}\text { It was necessary to know the balance of } \\
\text { the stock and the information took longer } \\
\text { than expected }\end{array}$ & 10 & 4,42 & 80,09 \\
\hline $\mathrm{J}$ & $\begin{array}{l}\text { Some employee demonstrated not to have } \\
\text { understood the instructions for stock } \\
\text { control, although he was trained }\end{array}$ & 5 & 2,21 & 82,30 \\
\hline K & $\begin{array}{l}\text { It was thought to optimize the capital } \\
\text { invested in stock without compromising } \\
\text { the quality of services provided }\end{array}$ & 20 & 8,85 & 91,15 \\
\hline $\mathrm{L}$ & $\begin{array}{l}\text { It was thought to create a manual of } \\
\text { operating procedures for the employees } \\
\text { who work in the inventory }\end{array}$ & 20 & 8,85 & 100,00 \\
\hline TA & & 226 & & \\
\hline
\end{tabular}

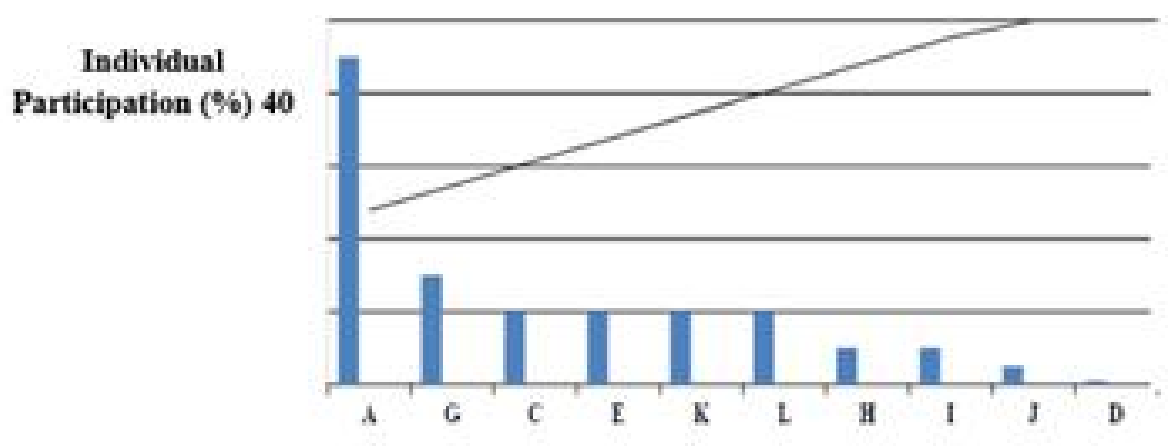

100

Accumulated

Participation

(\%)

Fig. 2: Parent of the identification of the failures in the control and planning of the Zeta Hotel stock, during a period of 90 days (one quarter)

According to the author [7], it can be concluded from the analysis of figure 2 that eliminating the flaws represented by $A$ and $G$, corresponds to solving $80 \%$ of the initial problems related to the control and planning of the Zeta Hotel stock. In other words, it becomes necessary to develop an inventory planning and control, which can be easily implemented by the hotel management.

Continuing the application of the quality tools selected to support the resolution of problems presented by Hotel Zeta, the Ishikawa diagram was applied in a third 
interview, considering the 4Ps indicated for the service operation. The data from this analysis are presented in Fig.
3.

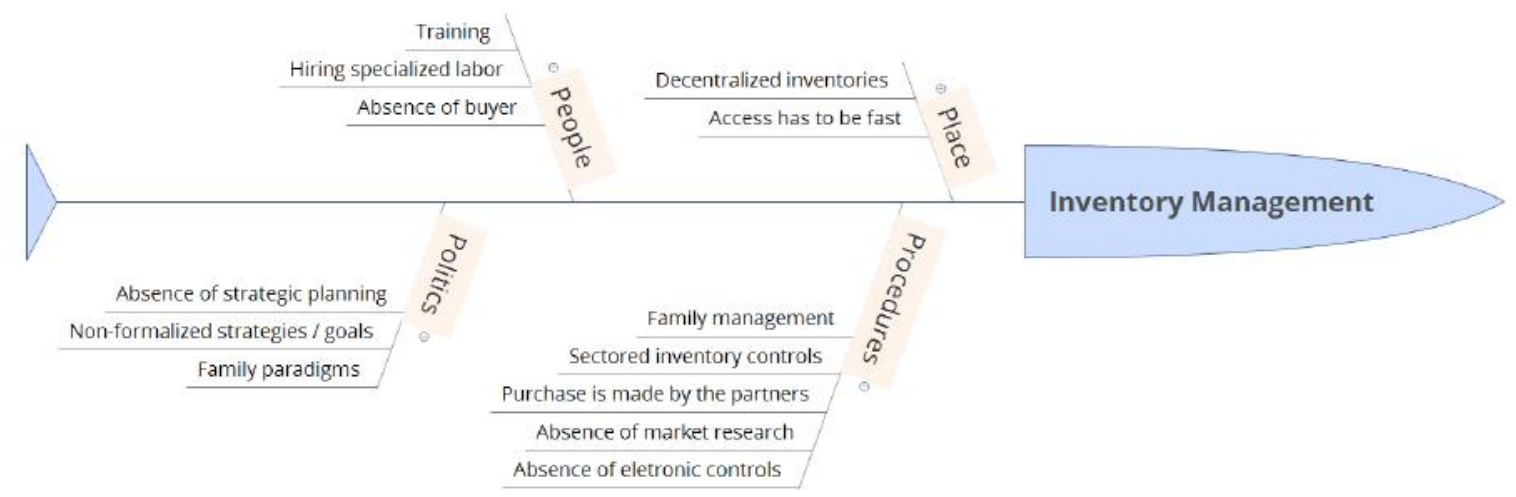

Fig. 3: Ishikawa diagram for the 4Ps

After this third interview, it was verified that the enterprise is a family business, which has sought a more professional management, through the hiring of managers with experience in other renowned chain hotels, but which also does not give up a more "familiar in some aspects" management by one of the partners. At the time, it is important to point out that this family management allowed for significant evolution not only in the physical accommodations of the undertaking, but also in the client portfolio. It was also observed that the employees are trained for the tasks performed and, currently, the hotel is hiring two new managers for the strategic areas of the business.
Continuing the suggestion of improvements, with a proposal adherent to the methods of control and production planning, a visit was made to observe the place of stock, the survey of resources employed (labor, equipment, financial and technological) and the layout adopted. With this data and other data related to the current stock control, the organization was organized in spreadsheets in order to analyze and apply the suggested procedures for decision making aiming at improving the reported problems. The summary of these spreadsheets was presented in Table 3.

Table 3: Survey of items in stock

\begin{tabular}{|c|c|c|c|c|c|}
\hline ITEM & UNIT & $\begin{array}{c}\text { ANNUAL } \\
\text { DEMAND } \\
\text { (UNID) }\end{array}$ & $\begin{array}{c}\text { AVERAGE } \\
\text { ANNUAL } \\
\text { COST (R\$ } \\
\mathbf{1 , 0 0 0 . 0 0 )}\end{array}$ & $\begin{array}{c}\text { ACCUMULATED } \\
\text { ANNUAL } \\
\text { DEMAND }(\mathbf{R} \$ \\
\mathbf{1 , 0 0 0 . 0 0})\end{array}$ & $\begin{array}{c}\text { ACCUMULATED } \\
\text { ANNUAL } \\
\text { DEMAND (\%) }\end{array}$ \\
\hline filet mignon & $\mathrm{kg}$ & 416 & 23.296 & 23.296 & 16,17 \\
\hline coffee capsule & unit & 5200 & 15.548 & 38.844 & 26,96 \\
\hline salmon piece & $\mathrm{kg}$ & 312 & 14.040 & 52.884 & 36,71 \\
\hline chicken filet & $\mathrm{kg}$ & 1040 & 10.192 & 63.076 & 43,78 \\
\hline papaya & unit & 2600 & 7.800 & 70.876 & 49,20 \\
\hline orange & box & 260 & 7.800 & 78.676 & 54,61 \\
\hline milk & unit & 1872 & 6.084 & 84.760 & 58,84 \\
\hline trout & unit & 520 & 5.720 & 90.480 & 62,81 \\
\hline multipurpose diprol 5 liters & bucket & 104 & 4.576 & 95.056 & 65,98 \\
\hline melon & unit & 1300 & 4.550 & 99.606 & 69,14 \\
\hline
\end{tabular}




\begin{tabular}{|c|c|c|c|c|c|}
\hline salted & unit & 1300 & 4.160 & 103.766 & 72,03 \\
\hline pineapple & unit & 1040 & 4.160 & 107.926 & 74,92 \\
\hline potato sticks bag $5 \mathrm{~kg}$ & bag & 156 & 3.588 & 111.514 & 77,41 \\
\hline gourmet hamburger & unit & 520 & 3.380 & 114.894 & 79,75 \\
\hline butter cookies & unit & 520 & 3.120 & 118.014 & 81,92 \\
\hline toilet paper & unit & 2600 & 2.080 & 120.094 & 83,36 \\
\hline strawberry & box & 520 & 2.080 & 122.174 & 84,81 \\
\hline beans & $\mathrm{kg}$ & 312 & 2.028 & 124.202 & 86,21 \\
\hline 5 liter diprol disinfectant & bucket & 52 & 1.872 & 126.074 & 87,51 \\
\hline cherry tomato & box & 416 & 1.456 & 127.530 & 88,52 \\
\hline chocolates & unit & 1560 & 1.404 & 128.934 & 89,50 \\
\hline apple & $\mathrm{kg}$ & 312 & 1.342 & 130.276 & 90,43 \\
\hline rice $5 \mathrm{~kg}$ & $\mathrm{~kg}$ & 104 & 1.300 & 131.576 & 91,33 \\
\hline waste bag 20 liters & one hundred & 52 & 1.300 & 132.876 & 92,24 \\
\hline water & unit & 1560 & 1.248 & 134.124 & 93,10 \\
\hline beer stella & unit & 312 & 1.111 & 135.234 & 93,87 \\
\hline american lettuce & unit & 624 & 936 & 136.170 & 94,52 \\
\hline 5 liter chlorine & bucket & 52 & 936 & 137.106 & 95,17 \\
\hline banana & dozen & 260 & 910 & 138.016 & 95,80 \\
\hline powder soap & package & 104 & 884 & 138.900 & 96,42 \\
\hline lemon & $\mathrm{kg}$ & 156 & 780 & 139.680 & 96,96 \\
\hline grape Italy & $\mathrm{kg}$ & 104 & 728 & 140.408 & 97,46 \\
\hline disposable cup & unit & 4160 & 624 & 141.032 & 97,90 \\
\hline coconut soap & package & 52 & 538 & 141.571 & 98,27 \\
\hline butox & unit & 156 & 524 & 142.095 & 98,63 \\
\hline disposable gloves & unit & 260 & 507 & 142.602 & 98,99 \\
\hline pen & unit & 780 & 437 & 143.038 & 99,29 \\
\hline tonner for printing & unit & 20800 & 416 & 143.454 & 99,58 \\
\hline floor cloths & unit & 312 & 312 & 143.766 & 99,79 \\
\hline A4 sheet & unit & 13000 & 260 & 144.026 & 99,98 \\
\hline pencil & unit & 104 & 35 & 144.062 & 100,00 \\
\hline
\end{tabular}

After collecting the stock data, and the organization in chart 3, Pareto's analysis was again applied, with the objective of elaborating the ABC curve that should indicate which items can be classified as $\mathrm{A}$, that is, although in small numbers they are responsible for most of the hotel's annual demand. These are the items selected to receive the greatest attention in stock control [14]. It can be observed that about fifteen items in the stock are responsible for $80 \%$ of the total accumulated value of the annual stock, these will be considered as the class A items in the stock. 


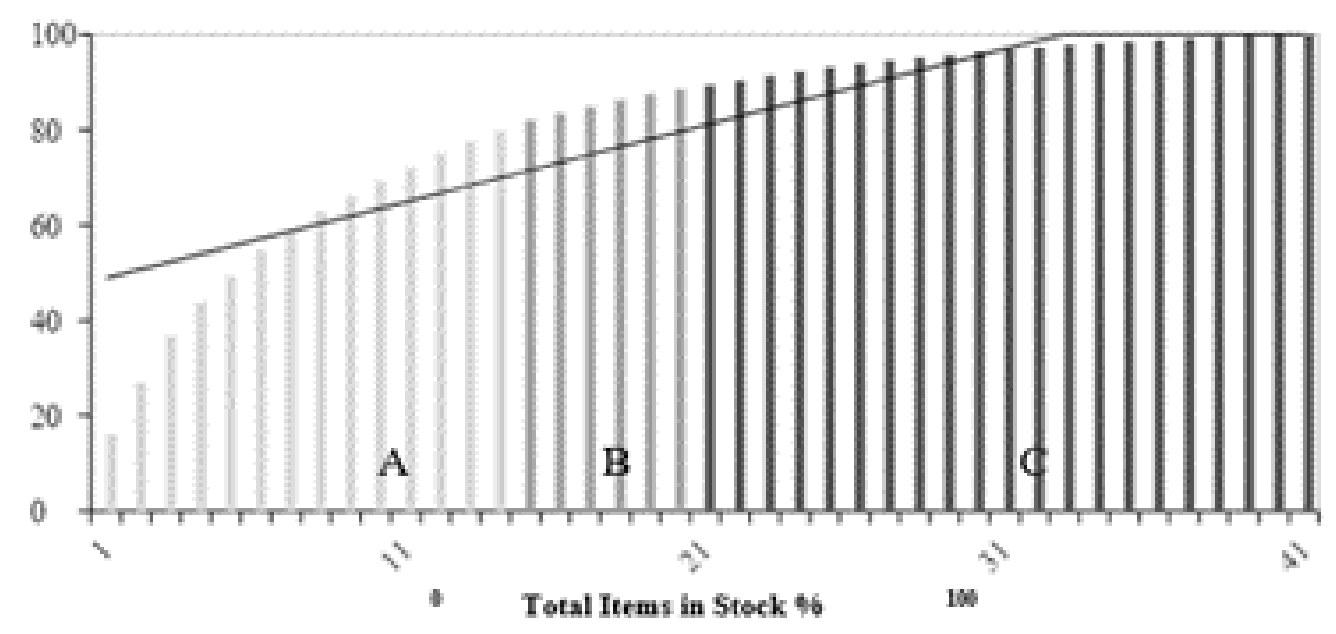

Fig. 4: ABC curve for the items in stock at Zeta Hotel

Fig. 4 shows that, according to the ABC Curve tool proposed by Ishikawa, approximately $20 \%$ of the items (A class items) represent about $80 \%$ of the annual stock demand (in R\$); the following 30\% of the items (B class items) represent $10 \%$ of this demand (in $\mathrm{R} \$$ ); and the remaining $50 \%$ of the items (C class items) represent $10 \%$ of the annual demand (in $\mathrm{R} \$$ ). Therefore, it is confirmed the need to more accurately manage the class A items, since they represent a significant portion of financial investments in the enterprise's stock [7].

Based on the class $\mathrm{A}$ items of the $\mathrm{ABC}$ Curve, and considering the costs involved in placing a purchase order for each of these items, the economic purchase lot (LEC) was calculated. According to [7] the LEC is configured as an approach to stock planning and control that assists in deciding how much to order for a certain item.

To exemplify this tool, and considering the coffee capsule item of class A, because it has a longer expiration date by which it does not lose its qualitative characteristics, the formula for calculation of LEC proposed by [7] was used. After a survey, considering the estimated costs for placing the order, stock maintenance and annual demand, a LEC corresponding to 252 was found, meaning that this is the best purchase quantity for this item for each purchase made. It is important to point out that, although Hotel Zeta maintains a portfolio of suppliers that deliver some products directly to the address where the project is located, the purchase for this item is made weekly and in fractioned quantities of 100. Therefore, if the LEC found was adopted, the enterprise could save both in the amount spent per trip (cost of the order), as well as in the value of each item, because usually for larger items, the cost per unit tends to decrease.
Once the value of the LEC is calculated, it becomes important to estimate the Security Stock, because even if the purchase is made directly by the hotel, it does not occur automatically: there is a time needed to place the order and it arrives and is available for the hotel's activities. This time is called lead time and is used to decide when it is necessary to place an order. Although these two values may vary, as they depend directly on the demand and the time in which the restocking will occur, their estimates tend to guarantee that the lack of stock will not occur and that the hotel will be able to meet its demand forecast [7].

All these issues, LEC, lead time, safety stock and order placement point were considered, from the approach of the [7] in the elaboration of the stock control spreadsheet and forwarded in the suggested improvement proposal to Hotel Zeta.

It should be noted that although the LEC approach and other issues mentioned above theoretically demonstrate many advantages for stock planning and control, there are some criticisms that deserve to be mentioned, such as the real costs of stock when in operation (which may not be adherent to the LEC model); not always minimizing the cost of stock is adequate, several factors must be considered; the model becomes simplistic, since it works with a certain stability of demand, with a fixed cost for placing the order, with a cost of stock maintenance expressed by a linear function and other variables that are not actually represented as they behave on a daily basis [7]. And, considering a stock that serves the hotel's food sector, the analysis should be even more incisive, because cost $\mathrm{x}$ savings factors should not be taken into account in the foreground, but the maintenance of product quality, 
expiration dates and the very control of perishable products.

\section{CONCLUSION}

The main objective of this study was to detail the reality of Hotel Zeta from a Production Engineering perspective, delimited by the application of PCP methodologies and tools and to present a solution proposal for one of the problems that was diagnosed in the company. After the initial data collection, through interviews with one of the owners, it was found that the problem to be analyzed in the study would be the hotel's stock management.

It can be concluded that the study met the proposed objective, since it demonstrated that the PCP methodologies and tools can be adopted to constitute an improvement in the management of the Hotel Zeta stock.

It is important to note that the results obtained with the study corroborate the bibliographies researched on PCP in small and medium enterprises, specifically in the services sector, confirming the absence of PCP applications in this sector and the possibilities of improvement, consequently, of profit maximization. As important as confirming these premises about PCP for this niche of companies, is to be able to conclude a bias of opportunities for the production engineer in the service sector.

Considering the analysis of all the data collected, the interviews and questionnaires, it can be affirmed that Hotel Zeta, although a profitable business with a family management that is giving positive results, has great potential to become even more productive, "leaner" and, consequently, more profitable, by applying the PCP methodologies and tools suggested in this study, which are easy to use through Microsoft Excel®.

As the study did not aim to exhaust the subject, and considering other possibilities within the areas of Production Engineering, other proposals for improvement can be researched and elaborated, such as the development of software or electronic systems to serve this part of the hotel market.

\section{ACKNOWLEDGEMENTS}

The authors wish to acknowledge the University of the State of São Paulo, Faculty of Engineerng of Guaratingueta, for its assistance during the research period.

\section{REFERENCES}

[1] Brazilian Association of the Hotel Industry of the State of São Paulo - ABIH-SP. (2019). A positive year for the hotel sector in São Paulo, with sales of approximately $\mathrm{R} \$ 8$ billion. Retrieved from http://www.abihsp.com.br/noticia/613/2019-02-14/anopositivo-para-setor-de-hotelaria-de-sao-paulo-comfaturamento-de-aproximadamente-r-8-bilhoes

[2] Brazilian Institute of Geography and Statistics - IBGE. (2019). Cities. Retrieved from https://cidades.ibge.gov.br/brasil/sp/pesquisa/34/62873acesso

[3] Slack, N., Chambers, S., \& Johnston, R. (2002). Administração da Produção (2 ed.). São Paulo, Editora Atlas.

[4] Laugeni, F. P. \& Martins G. P. (2006). Production Administration (2 ed.). São Paulo, Editora Saraiva.

[5] Lustosa, L.; Mesquita, M. A.; Quelhas, O.; \& Oliveira, R. J. (2011). Production Planning and Control (1 ed.). Rio de Janeiro, Elsevier Editora Ltda.

[6] Lemos, A. C. D. (1999). Aplicação de uma Metodologia de Ajuste do Sistema Kanban em um Caso Real Utilizando a Simulação Computacional. Dissertação de mestrado, Universidade Federal de Santa Catarina, Florianópolis, Brasil.

[7] Slack, N.; Chambers, S.; \& Johnston, R. Production Administration (3 ed.). (2009). São Paulo, Atlas Publishing.

[8] Brazil. (2019). Resolution No. 2, of April 24. Institutes the National Curricular Guidelines for the Undergraduate Course in Engineering. Retrieved from http://portal.abepro.org.br/wpcontent/uploads/2020/05/RESOLUÇÃO-Nº-2-DE-24-DEABRIL-DE-2019-RESOLUÇÃO-No ${ }^{\circ}$-2-DE-24-DE-ABRILDE-2019-DOU-ImprensaNacional.pdf

[9] Barros Filho, J. R. (1999). Methodology for implementation and improvement of production planning and control in small and medium enterprises. Dissertação de mestrado, Universidade Federal de Santa Catarina, Florianópolis, Brasil. Retrieved from https://repositorio.ufsc.br/xmlui/bitstream/handle/12345678 9/80761/143956.pdf?sequence $=1 \&$ isAllowed $=\mathrm{y}$

[10] Serviço Brasileiro de Apoio às Micro e Pequenas Empresas - SEBRAE. (2019). Small Business in Number. Retrieved from

https://www.sebrae.com.br/sites/PortalSebrae/ufs/sp/sebraea z/pequenos-negocios-em numeros, 12e8794363447510VgnVCM1000004c00210aRC $\mathrm{RD}$

[11] Lashley, C. \& Morrison, A. (2004). In search of hospitality: perspectives for a globalized world (1 ed.). Barueri, SP: Manole.

[12] Morais, B. M., Silva, M. D. A., \& Guimaraes, I. F. G. (2019). An analysis of Service Planning and Control in the Hotel Sector of a Historic City. Retrieved from http://www.abepro.org.br/biblioteca/TN_STO_238_384_33 836.pdf

[13] Palomino, R., Silveira, R. O., Oliveira, R., Moura, T., \& Santana, O. L. (2019). Application of the ABC curve in the stock management of a micro company in Aracaju-SE. 
Retrieved from http://www.abepro.org.br/biblioteca/TN_STP_258_480_359 28.pdf

[14] Corrêa, H. L. \& Corrêa, C. A. (2012). Production Management (3 ed.). São Paulo: Atlas.

[15] Gomes, A. C. N., Ferreira, A. R. S. V., Borges, F. H., \& Silva, E. B. (2018). The application of quality tools in the creation of standardized operating procedures in two media restaurants in Rio de Janeiro. Exacta - EP, São Paulo, 16(2), 95-106. Retrieved from https://periodicos.uninove.br/exacta/article/view/7066/3789

[16] Ishikawa, K. (1985). What Is Total Quality Control? The Japanese Way (1st ed.). Englewood Cliffs, New Jersey: Prentice-Hall.

[17] Bezerra, F. M. (2014). Planejamento e controle da produção em uma pequena organização produtiva: da concepção à implantação. Dissertação de mestrado, Universidade Federal do Rio de Janeiro, Rio de Janeiro, Brasil. Retrieved from http://www.producao.ufrj.br/index.php/br/teses-edissertacoes/mestrado/2014/54--47/file

[18] Tripp, D. (2005). Research-action: a methodological introduction. Educação e Pesquisa (ISSN 1678-4634), 31(3), 443-466. https://doi.org/10.1590/S151797022005000300009 . 